\title{
これからの原子カシステムを担う 新原子力材料
}

\author{
次世代原子カシステムのための材料開発の現状と課題
}

\section{第 3 回 酸化物分散強化型 (ODS) フェライト鋼}

\author{
北海道大学 鵜飼 重治, \\ 日本原子力研究開発機構 大塚 智史, 皆藤 威二
}

高温強度と耐照射性に優れた ODS フェライト鋼を Na 冷却高速増殖炬の燃料被覆管に適用す ベく, 日本原子力研究開発機構が中心になって一貫した実用化技術開発が進められている。また, 鉛ビスマスや超臨界圧水冷却材に対する優れた耐食性を有する $\mathrm{Al}$ 添加高 CrODS 鋼も京都大学 を中心に開発が進められている。これらは我が国の独自技術として国際的にも注目され，その期 待度は大きい。

\section{I. 緒 言}

耐照射性が格段に優れたフェライト鋼をベースに、そ の高温強度を大幅に向上させるため, 酸化物粒子を微細 に分散した酸化物分散強化型(Oxide Dispersion Strengthened) フェライト鋼 (ODS 鋼と略記)の開発が進 められている。酸化物粒子として用いられるイットリア $\left(\mathrm{Y}_{2} \mathrm{O}_{3}\right)$ はメカニカルアロイングによる粉末の合金化過程 でいったん分解した後, 添加したチタンと高温焼結時に 反応してナノスケールの複合酸化物 $\left(\mathrm{Y}_{2} \mathrm{Ti}_{2} \mathrm{O}_{7}\right)$ 粒子とし て微細析出し高温強化に寄与する。しかしミリスケール のバルク強度は結晶粒界等の弱化因子の影響を受けやす く, 単純な分散強化では予測できない。ODS 鋼は他の 金属材料に比べこのような弱化因子に敏感な特徵がある ため, 加工熱処理によるメゾスケール(結晶粒径相当の ミクロンサイズ)の組織制御が被覆管製造では特に重要 である。

ODS 鋼は国際的な第 4 世代 (Generation IV) 原子炉の 燃料被覆管候補材であり, また次世代核融合炉のブラン ケット構造材料としても期待されている。我が国ではそ れほど認識されていないが, ODS 鋼の開発研究は国際 的には極めて活発であり, 昨年開催された核融合炉材料 国際会議での発表件数は，フェライト鋼が47件であった のに対し, ODS 鋼は43件とほぼ同数であり, 酸化物粒

Materials for New Generation Nuclear Energy SystemsCurrent State and Future Agenda for Material Developments(3); ODS Ferritic Steels: Shigeharu UKAI, Satoshi OHTSUKA, Takeji KAITO.

(2012年 5 月29日 受理)

口前回のタイトル

第 2 回 低放射化フェライト鋼
子のナノ制御モデリングからバルク強度の評価, 照射効 果に至る基礎的研究成果が多数報告された。ODS 鋼の 実用化に関しては, 日本原子力研究開発機構 (原子力機 構と略記) を中心に高速増殖炉用燃料被覆管の製造・製 管技術，検查技術，端栓との接合技術，照射影響評価， 材料強度基準の整備など，一貫した実用化技術開発がな されており，国際的にも大変注目されている。

本稿では, 原子力機構が進めている $\mathrm{Na}$ 冷却高速増殖 炉用 $9 \sim 12 \mathrm{CrODS}$ 鋼被覆管の開発を中心に概説すると ともに，鉛ビスマスや超臨界圧水冷却材に対する耐食性 に優れた $\mathrm{Al}$ 添加高 CrODS 鋼の開発研究や核融合炉ブ ランケット構造材料としての適用研究についても紹介す る。

\section{9〜12 CrODS 鋼被覆管の開発}

\section{ODS 鋼被覆管の開発経緯と要求性能}

\section{(1) 開発経緯}

安全性・経済性に優れた高速増殖炉サイクルを実現す るためには，高燃焼度化によるサイクルコスト低減，高 出口温度化による発電効率向上が不可欠である。発電効 率の向上は，コスト削減のみならず，単位発電量あたり の放射性廃棄物量を低減するため，環境負荷低減の観点 でも重要である。原子力機構では，これらを達成し得る 燃料被覆管材料として ODS 鋼に注目し，1980年代から 開発に着手した。1999年 7 月から2006年 3 月まで実施 した実用化戦略調查研究 (FS: Feasibility Study), 引き 続いて2011年 3 月まで実施した高速増殖炉サイクル実用 化研究開発 $(\mathrm{FaCT}$ : Fast Reactor Cycle System Technology Development Project)フェーズ Iの一連の プロジェクトにおいて，一貫して ODS 鋼を将来のナト 
リウム冷却高速増殖炬燃料被覆管の第 1 候補材料と位置 づけて開発を進めてきた1)。

一般にフェライト系材料の場合, 過度に $\mathrm{Cr}$ 濃度を増 量すると, $500^{\circ} \mathrm{C}$ 未満の低温側での熱時効や中性子照射 効果により 2 相分離 (Cr リッチな $\alpha$ プライム相の析出) が生じ，延性が低下することが懸念される。そこで ODS 鋼被覆管の $\mathrm{Cr}$ 濃度は $9 \sim 12 \mathrm{wt} \%$ に設定したうえで， 耐照射性と加工性を重視したマルテンサイト系 9 CrODS 鋼を第 1 候補とし，耐食性に優れたフェライト 系12 CrODS 鋼をバックアップと位置づけて，それらの 開発を行ってきた。第 1 表に 9 CrODS 鋼被覆管と 12 CrODS 鋼被覆管の基本組成を示す。

\section{（2）燃料被覆管の要求性能}

第 1 図に FaCT で開発を進めている JSFR (Japan sodium cooled fast reactor)の燃料集合体および然料要 素を模式的に示す。外径 $10 \mathrm{~mm}$ 程度, 肉厚 $0.5 \sim 1.0 \mathrm{~mm}$ 程度の被覆管にMOX 燃料ペレットを充填した燃料要素 255本が一つの集合体に収納され，この燃料集合体562体 が炉心に装荷される。JSFR の場合，冷却材出口温度は $550^{\circ} \mathrm{C}$, 取出平均燃焼度は約 $150 \mathrm{GWd} / \mathrm{t}$ であり,これに 対応する被覆管の最高温度は $700^{\circ} \mathrm{C}$, はじき出し損傷量 は約250 dpa (displacement per atom)に達する。開発す る ODS 鋼被覆管にはこのような高温・高燃焼度に耐え る高温強度と耐照射性のみならず，核分裂生成物 (FP) による内面腐食, 冷却材ナトリウムによる外面腐食と いった複合環境に対する耐性も要求される。

\section{2. 組織制御および高温クリープ強度特性}

\section{（1）９ CrODS 鋼被覆管}

ODS 鋼被覆管の製造プロセスは，粉末冶金法による 素管製造と冷間圧延による製管プロセスからなる(第 2 図)。上行程の素管製造は, 金属・合金粉末とイットリ ア粉末をボールミルでメカニカルアロイング処理し，熱 間押出しで固化成形するプロセスで, 従来の溶解法とは 大きく異なる。ODS 鋼被覆管を製造する上での最大の 難点は，難加工材である ODS 鋼を冷間圧延で薄肉長尺 の被覆管にまで加工する製管プロセスにある。そこで，
第 1 表 $9 \mathrm{Cr}$ および $12 \mathrm{CrODS}$ 鋼被ふく管の基本組成

\begin{tabular}{c|cccccc|cc}
\hline \multirow{2}{*}{} & \multicolumn{5}{|c|}{ 化学組成 $(w t \%)$} & & 計算值 $(w t \%)$ \\
\cline { 2 - 9 } & $\mathrm{C}$ & $\mathrm{Ni}$ & $\mathrm{Cr}$ & $\mathrm{W}$ & $\mathrm{Ti}$ & $\mathrm{Y}$ & $\mathrm{Y}_{2} \mathrm{O}_{3}^{\mathrm{a}}$ & $\left.\mathrm{Ex} . \mathrm{O}^{\mathrm{b}}\right)$ \\
\hline 9Cr-ODS & 0.13 & $<0.20$ & 9 & 2.0 & 0.20 & 0.28 & 0.35 & 0.07 \\
\hline $12 \mathrm{Cr}-\mathrm{ODS}$ & 0.03 & $<0.20$ & 12 & 2.0 & 0.26 & 0.18 & 0.23 & 0.07 \\
\hline
\end{tabular}

${ }^{a)} \mathrm{Y}$ が全て $\mathrm{Y}_{2} \mathrm{O}_{3}$ の形態で存在すると仮定した場合の計算值 b) 全酸素量分析值から， $\mathrm{Y}_{2} \mathrm{O}_{3}$ 中の酸素量を差し引いた過剩酸 素量

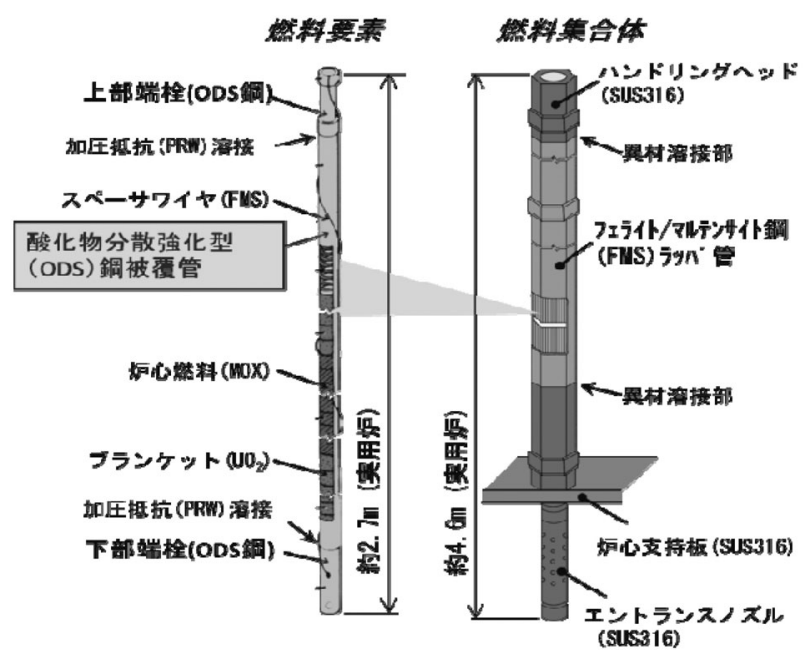

第 1 図 JSFR 燃料集合体および燃料要素の模式図

マルテンサイト系 $9 \mathrm{CrODS}$ 鋼では， $\alpha / \gamma$ 変態を積極的 に利用し軟化したフェライト相状態で最終被覆管形状ま での冷間圧延を行った後，圧延方向に伸長した結晶粒を 最終焼ならし・焼戻し熱処理で等軸化するという新しい 技術を開発し ${ }^{2)}$ ，この課題を克服した。製造した 9 CrODS 鋼被覆管の欠陥検査においても, 従来の超音波探傷検査 技術を改良することで対応可能である。

$9 \mathrm{CrODS}$ 鋼被覆管の組織を第 3 図に示す。計算状態 図に基づくとマルテンサイト単相になるが，実際には残 留 $\alpha$ フェライトと名付けたフェライト相との複相組織 である。残留 $\alpha$ フェライトとは, 高温熱処理時に, ナ ノスケールの酸化物粒子によるピンニング効果により， $\alpha / \gamma$ 逆変態が進行せず， $\alpha$ フェライトのまま残った相

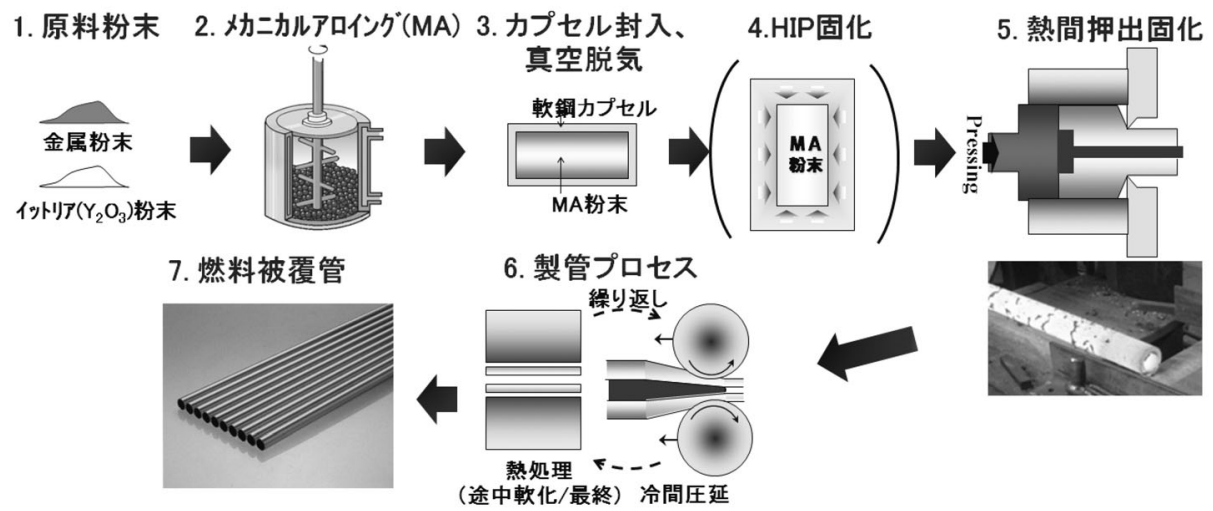

第 2 図 ODS 鋼被覆管の製造プロセス 


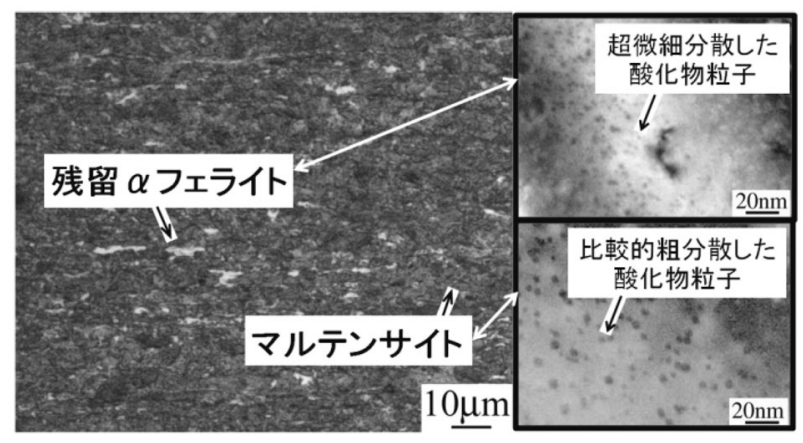

第 3 図 $9 \mathrm{CrODS}$ 鋼被覆管の金相組織(縦断面) と 酸化物ナノ粒子の透過型電子顕微鏡像

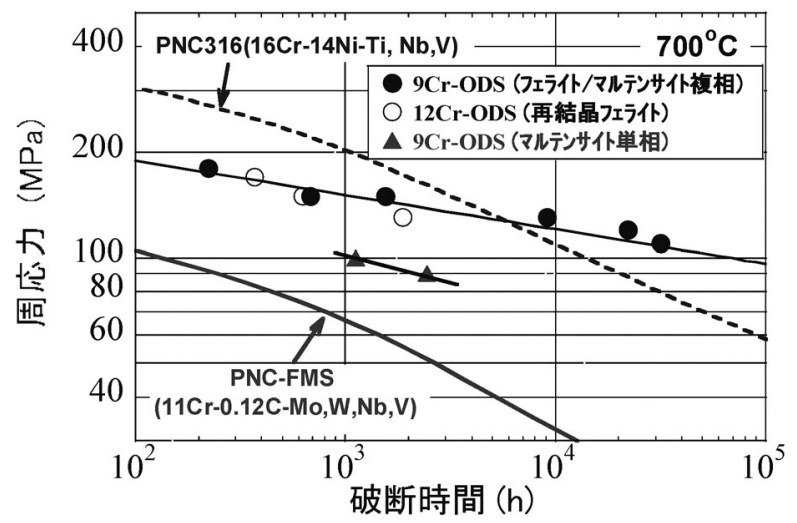

第 4 図 ODS 鋼被覆管の炉外高温内圧クリープ破断強度

である ${ }^{3)}$ 。残留 $\alpha$ フェライト相中では, 転位密度が高く, 酸化物粒子も微細かつ高密度に分散しており，有効な強 化相として機能する。第 4 図に示す内圧クリープ破断強 度から, 焼戻しマルテンサイト単相に比べ, 残留 $\alpha$ フェ ライトを含む複相組織とすることにより, 破断時間が 1 〜 2 桁伸びることが分かる。これはマルテンサイト相中 のブロック境界などで生じる局所的な変形促進に対し， 硬質の残留 $\alpha$ フェライト相が複合材料的に変形抵抗と して働くことに因る ${ }^{4)}$ 。通常のフェライト系耐熱鋼の場 合はフェライト相は軟質相で高温強度の低下要因となる ことを考えると，これは ODS 鋼に特有の挙動で材料学 的にも興味深い。

\section{（2） 12 CrODS 鋼被覆管}

$\alpha / \gamma$ 相変態のないフェライト系 $12 \mathrm{CrODS}$ 鋼では, 回復軟化を利用して製管した後, 加工方向に伸びた結晶 粒を再結晶組織として等軸・粗大化させる。しかし， $\alpha$ $/ \gamma$ 変態の駆動力が数百 $\mathrm{MJ} / \mathrm{m}^{3}$ であるのに対し, 再結晶 の駆動力は数 $\mathrm{MJ} / \mathrm{m}^{3}$ と 2 桁低く再結晶の再現性が十分 でないため, 量産規模で均質な再結晶組織を保証するた めには，いまだ製造上の課題が残されている。均質な再 結晶組織を有する $12 \mathrm{CrODS}$ 鋼被覆管のクリープ破断強 度は，9CrODS 鋼被覆管と同等レベルである (第 4 図)。
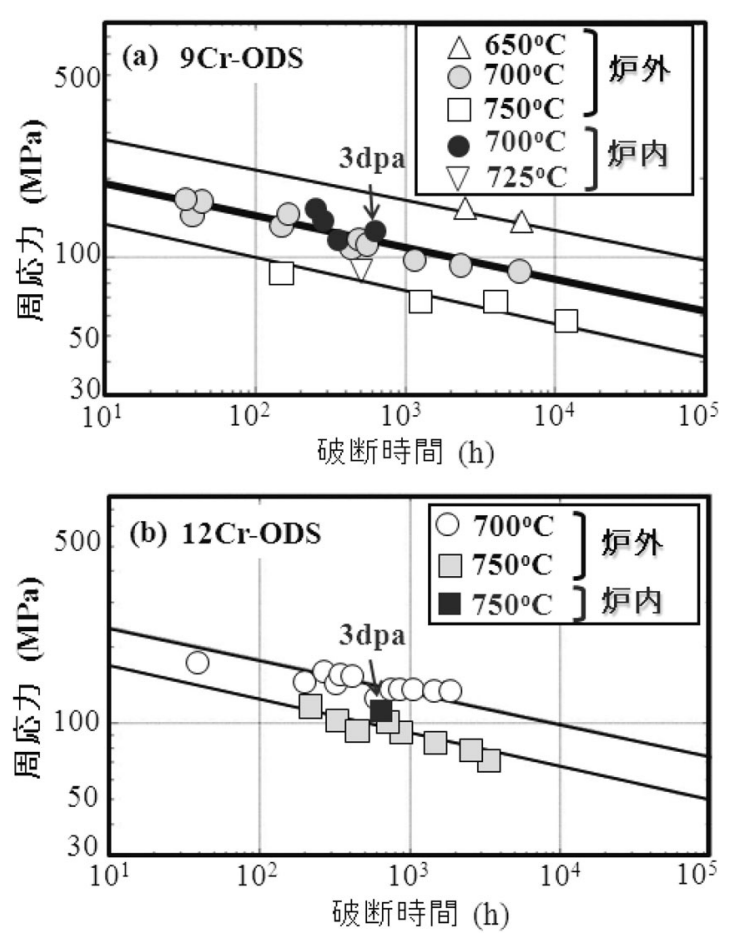

第 $\mathbf{5}$ 図 ODS フェライト鋼被覆管の炉内高温内圧クリープ 破断強度

\section{3. 照射試験}

$9 \mathrm{CrODS}$ 鋼被覆管と $12 \mathrm{CrODS}$ 鋼被覆管から作製した 内圧クリープ試験片を用いて，「常陽」で炉内高温クリー プ破断試験を行った結果を第 $\mathbf{5}$ 図に示す5)。照射量は 3 dpa と必ずしも高くないが，両被覆管ともに高温照射下 でクリープ強度の低下が全くないことは注目すべき成果

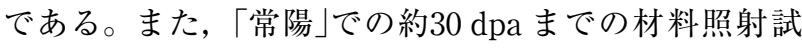
験において， $835^{\circ} \mathrm{C}$ の高温照射後においても両被覆管と もに優れた高温強度を維持することを確認している。

$9 \mathrm{Cr}$ および $12 \mathrm{CrODS}$ 鋼被覆管製燃料ピンからなる試 験集合体をロシアの高速実験炉 BOR-60で照射し，ODS 鋼被覆管製燃料ピンとしては世界的に経験のないピーク 燃焼度 $112 \mathrm{GWd} / \mathrm{t}$ までの範囲で破損等の不具合なく照 射試験を完了している。一方で，ピーク燃焼度が $98 \mathrm{GWd}$ $/ \mathrm{t}$ の試験集合体で $9 \mathrm{CrODS}$ 鋼被覆管 1 本に破損が生じ た。この原因は照射温度異常と被覆管組織の不均質によ ることが判明しており，これに対応すべく均質性改善の ための製造技術改良の見通しを現在までに得ている。

\section{4. 今後の課題}

ODS 鋼被覆管の実用化に向けた今後の課題として は，量産技術を開発し，粉末治金特有の不均質性を排除 して安定的に均質な被覆管を製造する技術を確立するこ とである。またこれと共に, 被覆管としての品質保証体 系を整備する必要がある。加えて, 燃料ピン照射試験に よる照射性能実証, 再処理時の被覆管硝酸溶解特性評価 も今後に残された重要な課題である。 


\section{III. $\mathrm{Al}$ 添加高 $\mathrm{CrODS}$ フェライト鋼の開発}

\section{1. 超臨界圧水や鉛ビスマス冷却材に対する耐食性}

冷却材に超臨界圧水や鉛ビスマスを用いた次世代高速 炉を想定して，これらの冷却材に対して優れた耐食性を 優する $\mathrm{Al}$ 添加高 $\mathrm{CrODS}$ フェライト鋼の開発が京都大 学を中心に進められた。

$\mathrm{Cr}$ 量の増量は耐食性の向上に有効であるが，一方， Crリッチ $\alpha$ ’相の出現に伴う熱時効脆化を促進させる ことが知られている。第 6 図は9CrODS, 16 CrODS, 19 CrODS について(それぞれ wt \%)，510C で25 MPa，600 時間の超臨界圧水による腐食試験を行った結果であ $ろ^{6)}$ 。溶存酸素量は 8 ppm であり, 比較のために SUS 430 の結果も示されている。腐食は酸化反応であり，これに よる重量増加を軽減するためには $\mathrm{Cr}$ 濃度を $19 \mathrm{Cr}$ 程度 まで上げる必要があるが，16 Crにして $\mathrm{Al}$ を $3.5 \mathrm{wt} \%$ 添加すると $19 \mathrm{Cr}$ と同等にまで耐食性を改善できる。こ れは試料表面に薄いアルミナ $\left(\mathrm{Al}_{2} \mathrm{O}_{3}\right)$ 酸化被膜が形成さ れることによる。アルミナ酸化被膜が形成されると, $\mathrm{Cr}$ 濃度が $14 \mathrm{Cr} \sim 19 \mathrm{Cr}$ の範囲で耐食性に差異がないことが 分かっている。この $\mathrm{Cr}$ 濃度範囲で熱時効脆化をどの程 度抑制できるかの見極めが今後の重要な課題である。

融点が $125^{\circ} \mathrm{C}$ と低い共晶組成の鉛ビスマス合金は, 次 世代高速炬の冷却材としてだけでなく, 加速器駆動核変 換システム $(\mathrm{ADS})$ の液体重金属ターゲットとしての採 用も検討されているが，鉛ビスマス合金中にはニッケ ル, 鉄, クロムが溶けやすいという課題がある。しかし，4 $\mathrm{Al}$ 添加の $14 \mathrm{CrODS}$ 鋼は $650^{\circ} \mathrm{C}$ で酸素濃度が $10^{-6} \mathrm{mass} \%$ $\mathrm{O}_{2}$ の鉛ビスマス合金中に 1 万時間浸漬してもほとんど腐 食しないことが確認されている。これは表面に形成され るアルミナ酸化被膜によるものである。従来から表面を 酸化被膜でコーティングする技術開発が行われてきた

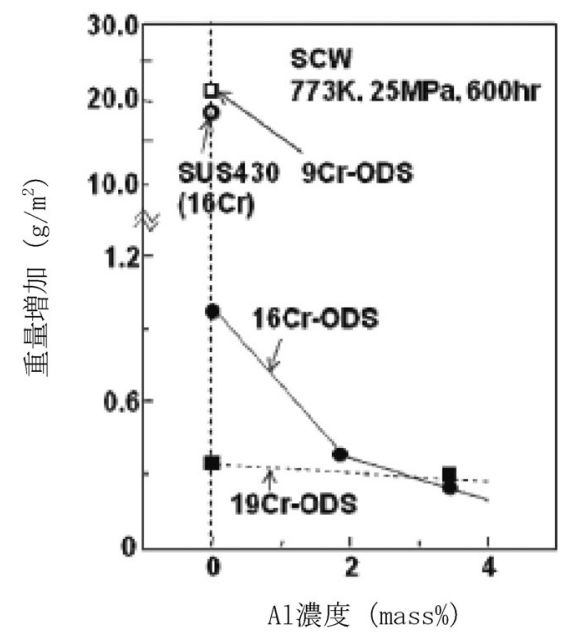

第 6 図 超臨界圧条件 $\left(510^{\circ} \mathrm{C}, 25 \mathrm{MPa}, 600 \mathrm{~h}\right)$ における 高 CrODS 鋼の酸化による単位表面積当たりの 重量増加と $\mathrm{Al}$ 濃度の関係
が， $\mathrm{Al}$ を合金化することでアルミナ酸化被膜の自己生 成・修復機能を発現できるというメリットが示された。

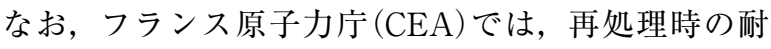
硝酸溶解特性や耐食性を重視して，Cr 濃度を $14 \sim 18 \mathrm{wt}$ \%まで増加したフェライト系 ODS 鋼被覆管の開発を 行っている。しかし, 現状の開発レベルは素材開発段階 にあり，今後の進展が期待される。

\section{2. 高温強度特性の改善}

耐食性の向上に有効な $\mathrm{Al}$ の添加は，逆に高温強度を 低下させることが知られている。II 章で述べた 9 CrODS 鋼や12 CrODS 鋼では，微細な $\mathrm{Y}_{2} \mathrm{Ti}_{2} \mathrm{O}_{7}$ 複合酸化物粒子 を高密度に分散させているが， $\mathrm{Al}$ 添加鋼では粗大な $\mathrm{YAlO}_{3}$ 複合酸化物となり数密度が低下するため，分散間 隔の広がりによる分散強化の低下が顕著となる。そこ で，4 Al 添加 $15 \mathrm{CrODS}$ 鋼に微量の $\mathrm{Zr}$ ，あるいは Hf を 添加することにより $\mathrm{Al}$ 無添加と同等のクリープ強度を 達成することに成功している7 。これは粗大な $\mathrm{YAlO}_{3}$ 複 合酸化物にかわって微細な $\mathrm{Y}-\mathrm{Zr}$ 複合酸化物，あるいは Y-Hf 複合酸化物が生成したことによることが高分解能 電顕による解析から明らかになっている。

\section{N．核融合炉ブランケット構造材料とし ての適用}

\section{1. 開発状況}

核融合炉ブランケット構造材料には，放射能レベルを 低減するため，モリブデン $(\mathrm{Mo})$ やニオブ $(\mathrm{Nb})$ をそれぞ れ低放射化元素であるタングステン $(\mathrm{W})$ やタンタル (Ta)で置き換えた低放射化フェライト鋼が開発されて いる。しかしその使用温度は $550^{\circ} \mathrm{C}$ 以下に制限されてお り，適用温度域を高温度側に拡大して熱効率の向上を図 るため，各国において低放射化 ODS フェライト鋼の開 発も積極的に進められている。

代表的な低放射化 ODS フェライト鋼とその主要成分 を第 2 表に示す。前述の高速増殖炉の燃料被覆管として 開発されている $9 \mathrm{CrODS}$ 鋼は，低放射化フェライト鋼 でもある。J 1 鋼と欧州の ODS-Eurofer 97は，それぞれ 低放射化フェライト鋼である F82H と Eurofer 97をべー

第 2 表 各国で開発されている代表的な核融合炉用低放射化 ODS 鋼 $($ wt \%)

\begin{tabular}{l|l|l}
\hline 9 CrODS 鋼 & $\mathrm{Fe}-9 \mathrm{Cr}-0.13 \mathrm{C}-2 \mathrm{~W}-0.2 \mathrm{Ti}-0.35 \mathrm{Y}_{2} \mathrm{O}_{3}$ & 日本 \\
\hline J 1 鋼 & $\begin{array}{l}\mathrm{Fe}-8 \mathrm{Cr}-0.16 \mathrm{C}-2 \mathrm{~W}-0.2 \mathrm{Ti}-0.18 \mathrm{~V}- \\
0.10 \mathrm{Ta}-0.37 \mathrm{Y}_{2} \mathrm{O}_{3}\end{array}$ & 日本 \\
\hline ODS-Eurofer 97 & $\begin{array}{l}\mathrm{Fe}-9 \mathrm{Cr}-0.08 \mathrm{C}-1 \mathrm{~W}-0.3 \mathrm{Mn}-0.2 \mathrm{~V}- \\
0.1 \mathrm{Ta}-0.5 \mathrm{Y}_{2} \mathrm{O}_{3}\end{array}$ & 欧州 \\
\hline $12 \mathrm{YWT}$ & $\begin{array}{l}\mathrm{Fe}-12 \mathrm{Cr}-0.05 \mathrm{C}-2.5 \mathrm{~W}-0.6 \mathrm{Mn}- \\
0.4 \mathrm{Ti}-0.25 \mathrm{Y}_{2} \mathrm{O}_{3}\end{array}$ & 米国 \\
\hline
\end{tabular}




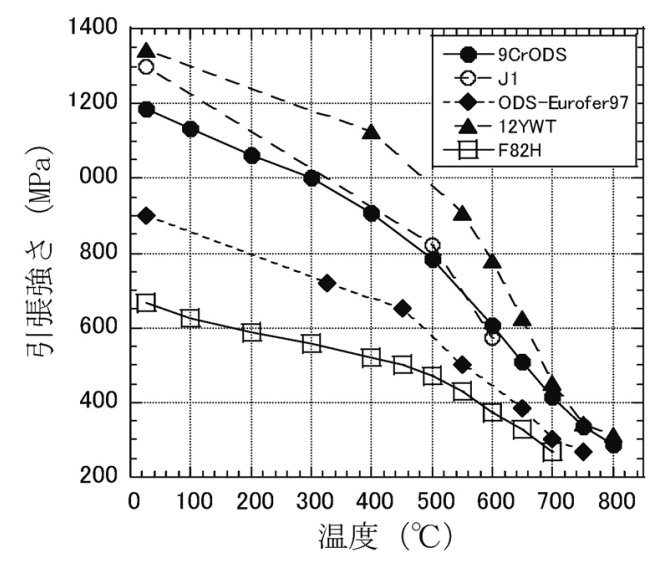

第 7 図 代表的な低放射化 ODS 鋼の引張強さ

スにイットリア $\left(\mathrm{Y}_{2} \mathrm{O}_{3}\right)$ を添加して酸化物分散強化を図っ たものである。 8 〜 $\mathrm{mass} \% \mathrm{Cr}$ を含有する $9 \mathrm{CrODS}$ 鋼, J 1 鋼, ODS-Eurofer 97は焼戻しマルテンサイト組 織であり, $\alpha / \gamma$ 逆変態を利用して等軸組織にすること ができる。一方， $12 \mathrm{mass} \% \mathrm{Cr}$ を含む $12 \mathrm{YWT}$ は，フェ ライト単相組織であるため再結晶処理による組織制御が 図られるが，十分ではなく加工方向に伸長した結晶粒形 態を有している。これら低放射化 ODS 鋼はブランケッ トを構成するパネルや冷却用パイプに加工する必要があ る。

\section{2. 基本特性}

第 2 表に示した各鋼種の引張強さを第 7 図に示す。比 較として, F82H の引張強さも示されている。Ti を含ま ない ODS-Eurofer 97では低放射化フェライト鋼 (F82 $\mathrm{H})$ からの強度増加が小さい。9 $\mathrm{CrODS}$ 鋼と J 1 鋼は同等 の強度レベルにあり，これら焼戻しマルテンサイト組織 では強度異方性は小さく, 十分な延性も確保されてい る。一方, フェライト単相である $12 \mathrm{YWT}$ の引張強さは 優れているが，これは引張軸が加工方向に平行な場合で あり，それと直角方向では強度・延性が低下するという 課題がある。ODS フェライト鋼を大型のブランケット 構造材料として用いる場合には, 薄肉被覆管では要求さ れない衝撃特性や破壊䩲性といった特性も重要となる。

\section{V. まとめ}

福島第一原子力発電所の甚大な事故の影響で, 我が国 の今後の高速増殖炉の開発計画は不透明な状況にある が，国際的には ODS 鋼への期待度はますます高まって
いる。2012年秋には欧州で ODS 鋼の核分裂炉/核融合 炉への適用に絞ったワークショップも予定されている。

原子力機構の ODS 鋼被覆管開発は量産技術開発へス テップアップする段階にあり, $\mathrm{Al}$ 添加高 CrODS 鋼を 含めて我が国の独自技術として, 今後の進展が大いに期 待される。

\section{一参 考 資 料一}

1) 日本原子力研究開発機構, 日本原子力発電, JAEAEvaluation-2011-003，(2011年 6 月).

2) 奥田隆成, 安部勝洋, 鵜飼重治, 水田俊二, 萩茂樹, 廣 畑憲明, 日本国第3171185号, 「酸化物分散強化型鋼の製 造方法」.

3) M. Yamamoto, S. Ukai, et al., J. Nucl. Mater., 417, 237240 (2011).

4) S. Ukai, S. Ohtsuka, et al., Mater. Sci. Eng. A, 510-511, 115-120(2009).

5) T. Kaito, S. Ohtsuka, et al., J. Nucl. Mater., 386-388, 294298 (2009).

6) A. Kimura, H.S. Cho, et al., J. Nucl. Sci. Technol ., 44, 323 $-328(2007)$.

7) T. Furukawa, S. Ohtsuka, et al., Proc. ICAPP, Tokyo, Japan, May 10-14, 2009, Paper 9221.

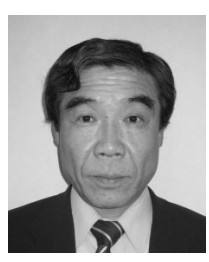

\section{著者紹介}

鵜飼重治(うかい・しげはる)

北海道大学

(専門分野/関心分野) 原子力材料, 高温材料, 材料強度学

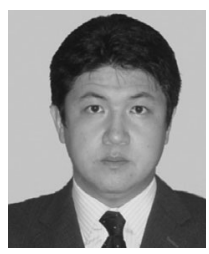

大塚智史 (おおつか・さとし)

日本原子力研究開発機構

(専門分野/関心分野) 原子力材料, 高速炉炬心材料開発

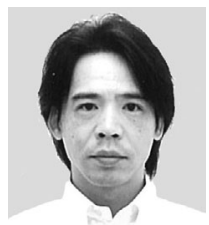

皆藤威二(かいとう・たけじ)

日本原子力研究開発機構

(専門分野/関心分野) 原子力材料, 高速炉炬心材料開発 